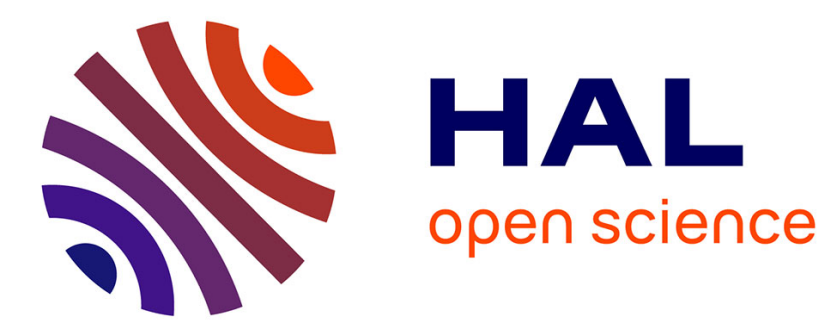

\title{
The effects of bovine somatotropin injections on mammary blood flow in dry and lactating dairy cows
}

H Rulquin, R Vérité

\section{To cite this version:}

$\mathrm{H}$ Rulquin, $\mathrm{R}$ Vérité. The effects of bovine somatotropin injections on mammary blood flow in dry and lactating dairy cows. Annales de zootechnie, 1993, 42 (2), pp.209-209. hal-00888937

\section{HAL Id: hal-00888937 https://hal.science/hal-00888937}

Submitted on 1 Jan 1993

HAL is a multi-disciplinary open access archive for the deposit and dissemination of scientific research documents, whether they are published or not. The documents may come from teaching and research institutions in France or abroad, or from public or private research centers.
L'archive ouverte pluridisciplinaire HAL, est destinée au dépôt et à la diffusion de documents scientifiques de niveau recherche, publiés ou non, émanant des établissements d'enseignement et de recherche français ou étrangers, des laboratoires publics ou privés. 


\title{
The effects of bovine somatotropin injections on mammary blood flow in dry and lactating dairy cows
}

\author{
H Rulquin, R Vérité
}

INRA, station de recherches sur la Vache laitière, 35590 Saint-Gilles, France

An improved milk yield due to bovine somatotropin (BST) was found to correspond to an increased mammary blood flow (Mepham et al, 1984) and cardiac output (Davis et al, 1988). As milk yield and mammary blood flow were closely related, we attempted to determine primary effects (blood flow or milk secretion) by comparing mammary blood flow responses to BST in lactating and dry cows.

Two dry and 3 lactating Holstein cows were used. Recombinant BST (Lilly France) was injected sc $(30 \mathrm{mg} / \mathrm{d})$ over an 8-d period. Daily mammary blood flow was measured in the common external pudic artery by ultrasound transittime blood flowmeter. Measurements were taken during the day before the first injection and on the first, 4th and 8th $d$ of injection as well as 2 and $8 \mathrm{~d}$ after the last injection. Results were expressed on a half-udder basis.
Lactating cows showed a significant increase $(P<0.05)$ in milk yield $(+1.3 \mathrm{~kg} / \mathrm{d})$ after the 4th injection (half-udder milk yield on $\mathrm{d} 0,1,4,8,10$ and 16 was $13.5,13.8$, $15.2,15.0,14.1$ and $13.5 \mathrm{~kg} / \mathrm{d}$ ). The blood flow: milk yield ratio was slightly increased (504 to $529 \mathrm{l} / \mathrm{kg}$ ) due to BST injections. The shape and level (maximum increase of $+0.7 \mathrm{l} / \mathrm{min}$ ) of the blood flow responses were quite similar to those obtained in dry cows (fig 1). These results suggest that an increased blood flow can be responsible for part of the BST effects on milk yield.

Davis SR, Collier RJ, Mc Namara JP, Head HH, Sussamn W (1988) J Anim Sci 66, 70-79

Mepham TB, Lawrence SE, Peters AR, Hart IC (1984) Hormon Metab Res 16, 248-253

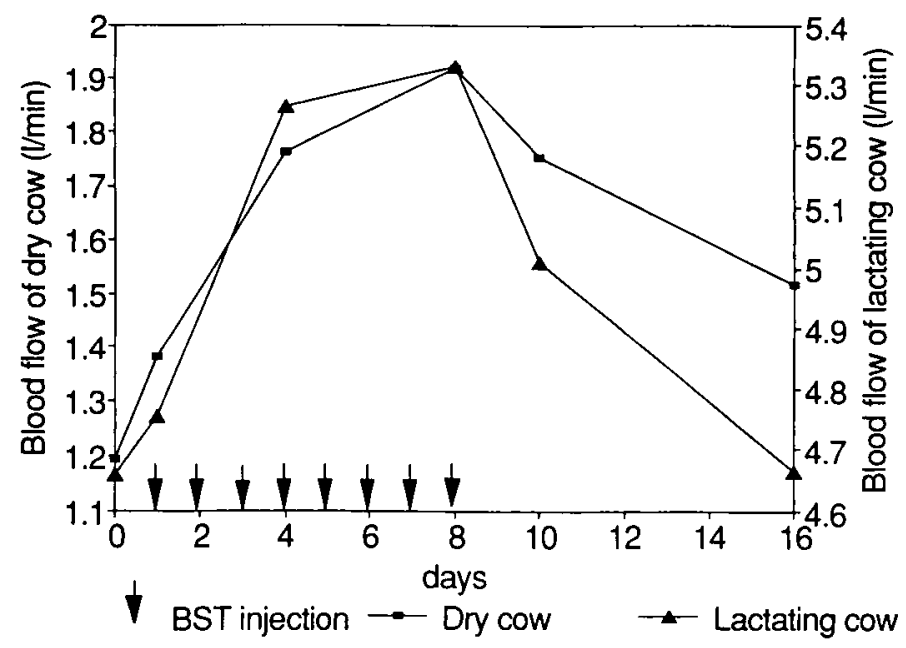

Fig 1. Effects of BST injections on half-udder blood flow. 